\title{
MENGANDUNG ANAK TAK SAH TARAF: KAJIAN KES DI DAERAH KUBANG PASU, KEDAH
}

\author{
Abd Ghani Ahmad \\ UUM COLGIS, \\ Universiti Utara Malaysia, Malaysia. \\ E-mel: agba9900@gmail.com \\ Nuarrual Hilal Md Dahlan \\ UUM COLGIS, \\ Universiti Utara Malaysia, Malaysia. \\ E-mel: nuarrualhilal@gmail.com, nuarrualhilal@uum.edu.my
}

Abstrak: Gejala hamil luar nikah dalam kalangan remaja menjadi isu besar dan sukar dibendung lagi. Pengaruh media sosial, pergaulan bebas dan kurang didikan agama dalam kalangan ibu bapa menjadi antara punca remaja hamil luar nikah. Keluarga merupakan pelindung utama dalam pembentukan sahsiah dan kesejahteraan psikologi golongan remaja agar tidak terpengaruh dengan masalah sosial yang tidak terkawal. Mengandung dan melahirkan anak tak sah taraf dalam usia muda menimbulkan keresahan kepada remaja tentang cara untuk 'menyelamatkan' anak tersebut daripada pengetahuan umum. Pelbagai isu dan masalah yang menyelubungi perasaan mereka sama ada ingin memelihara sendiri anak tersebut atau menyerahkan sahaja kepada keluarga angkat. Objektif kajian ini dilakukan adalah untuk mengetahui sejauh manakah penerimaan remaja hamil luar nikah dan keluarga terhadap anak tersebut. Kajian ini berbentuk kualitatif berdasarkan kajian-kajian terdahulu menerusi pelbagai buku, jurnal dan dokumen yang membincangkan isu remaja hamil luar nikah. Kaedah tinjauan digunakan untuk mengenal pasti pandangan para responden tentang penerimaan mereka terhadap kelahiran anak tak sah taraf. Pengumpulan data diperoleh dengan menggunakan metode temu bual berstruktur yang menjadi asas utama dalam kajian ini. Analisis perbandingan dilakukan terhadap data yang dikumpulkan dan dikategorikan kepada lima isu penting sama ada bersifat positif atau negatif dan sama ada terdapat persamaan atau perbezaan dari aspek penjagaan, pendidikan, pengurusan dan kebajikan, emosi dan perasaan serta akhlak dan perubahan sikap remaja tersebut. Hasil kajian mendapati bahawa remaja dan ahli keluarga mereka boleh menerima kelahiran anak tak sah taraf dan 
bersifat positif tentang kepentingan menjaga anak tersebut. Terdapat persamaan antara mereka dari aspek pendidikan, pengurusan dan kebajikan, emosi dan perasaan serta akhlak dan perubahan sikap. Walau bagaimanapun, terdapat perbezaan dari aspek penjagaan anak tersebut iaitu ada antara remaja dan ahli keluarga sanggup memelihara sendiri dan sebaliknya ada yang menyerahkan kepada keluarga angkat.

Kata kunci: Remaja, Pergaulan bebas, Hamil luar nikah, Anak tak sah taraf, Keluarga angkat.

Abstract: Symptoms of pregnancy outside marriage among teenagers has become a big issue and still unresolved. This catastrophe is due to the influence of social media, promiscuity and lack of proper religious education among the said teenagers. Family is the main factor in the formation of personality and psychological well-being of teenagers against any bad influenced. Pregnancy and giving birth to an illegitimate child at young age has caused anxiety to young people to the face the issue on how to 'save' the child from public knowledge. Various issues and problems will occur including the issue of maintenance the child ie. Whether to maintain the children themselves or to hand over it to adoptive family. The objective of this study is to determine the extent of acceptance of teenagers 'pregnancy outside marriage. This writing is a qualitative case study writing based on previous studies through various secondary sources that discussed the issue of teenage pregnancy out of wedlock. The survey method was also used to identify the respondents' view of their acceptance of illegitimate children. Data were also collected using a structured interview method. A comparative analysis was conducted on data collected and categorized into five key issues either positive or negative and whether there are similarities or differences in the aspects of care, education, and welfare management, emotions and feelings as well as moral and change the behaviour of teenagers. The study found that adolescents and their family members can accept their illegitimate children and are ready to look after the child. There are similarities between them in terms of education, management and welfare, emotions and feelings as well as moral and attitudinal changes. However, there are differences in the aspects of illegitimate child care among adolescents and family members who are unable to maintain the children and this had caused them to send the children to host family. 
Keywords: Teenagers, Free intercourse, Pregnancy outside marriage, Illegitimate children, Host family.

\section{PENGENALAN}

Remaja hari ini sangat terdedah dengan masalah sosial yang wujud dalam persekitaran hidup mereka. Gejala sosial yang melibatkan golongan remaja dilihat semakin bertambah apabila banyak dalam kalangan mereka terjerumus ke dalam aktiviti yang kurang sihat sehingga mengancam kehidupan masyarakat di negara ini. Pelbagai jenis kesalahan jenayah yang membabitkan harta benda dan jiwa manusia berlaku dalam masyarakat. Golongan remaja terlibat dengan kes mencuri, meragut, mencabul kehormatan, merogol, hubungan seks bebas, sumbang mahram bahkan terlibat dengan kes pembuangan bayi. ${ }^{1}$ Segala salah laku remaja berpunca daripada pengaruh media massa, penggunaan media sosial yang boleh dicapai melalui aplikasi telefon mudah alih, pergaulan bebas dan peranan ibu bapa yang kurang memberi perhatian terhadap pembinaan akhlak yang mulia serta tiada pendidikan agama yang sempurna menjadi penyebab gejala hamil luar nikah dalam kalangan remaja.

Menurut YB Datuk Dr. Wan Junaidi Tuanku Jaafar, Timbalan Menteri Dalam Negeri dalam persidangan Parlimen Malaysia bertarikh 18 \& 19 Mac 2014 tentang kelahiran anak luar nikah oleh gadis bawah umur (16 tahun ke bawah) dalam tahun 2012 2013, jumlah anak luar nikah oleh gadis bawah umur (perangkaan daripada JPN) yang melibatkan bangsa Melayu ialah 1,490 orang manakala bukan Melayu ialah 1,836 orang. Bagi kes rogol gadis bawah umur yang dilaporkan kepada polis yang melibatkan bangsa Melayu ialah 2390 orang manakala bukan Melayu ialah 584 orang. Bagi kes rogol gadis bawah umur yang tidak dilaporkan kepada polis hanya melibatkan bukan Melayu sahaja iaitu 1,252 orang. ${ }^{2}$

Fariza Md. Sham et.al, "Ciri-ciri Remaja Berisiko: Kajian Literatur”, Islamiyyat, UKM, Vol. 35, No.1, 2013, hlm.111 - 119.

2 Wan Hamzah Wan Paie, "Isu Terhadap Jawapan TMDN mengenai statistik kes rogol gadis bawah umur", Kenyataan Media, 21 Mac 2014, http://www.moha. gov.my/index.php/en/kenyataan-media-akhbar/1513-isu-terhadap-jawapan-ybtmdn-mengenai-statistik-kes-rogol-gadis-bawah-umur /21 Mac 2014, capaian pada 1 Mei 2014. 
Merujuk statistik yang dikeluarkan oleh Jabatan Pendaftaran Negeri Kedah, jumlah kelahiran anak tak sah taraf bagi negeri Kedah bagi tahun 2014 ialah 1219 orang. Daerah Kuala Muda mencatat jumlah tertinggi iaitu 267 orang atau 21.9\% manakala daerah Bandar Baharu mencatat jumlah paling rendah iaitu 9 orang atau $0.74 \%{ }^{3}$

Hamil luar nikah ditakrifkan sebagai mengandung sebelum berkahwin apabila berlaku hubungan seks antara dua pasangan yang tidak mempunyai pertalian nikah yang sah. Remaja hamil luar nikah melibatkan peringkat umur antara 13 hingga 18 tahun. ${ }^{4}$ Fenomena mengandung dan melahirkan anak tak sah taraf dalam usia muda menimbulkan keresahan kepada remaja tentang cara untuk 'menyelamatkan' anak tersebut daripada pengetahuan umum. Pelbagai isu dan masalah yang menyelubungi perasaan mereka sama ada ingin memelihara sendiri anak tersebut atau menyerahkan sahaja kepada keluarga angkat.

\section{OBJEKTIF KAJIAN}

Kajian ini dilakukan untuk mengetahui sejauh manakah penerimaan remaja hamil luar nikah dan keluarga mereka terhadap anak yang dilahirkan sebagai anak tak sah taraf.

\section{METODOLOGI KAJIAN}

Reka bentuk kajian ini menggunakan kaedah kualitatif yang melibatkan kajian kes. ${ }^{5}$ Kaedah ini munasabah kerana kajian tentang fenomena mengandung anak tak sah taraf melibatkan remaja hamil luar nikah memerlukan tinjauan yang mendalam untuk mengenal pasti isu dan masalah yang berlaku serta mencari jalan penyelesaian. ${ }^{6}$

\footnotetext{
Jabatan Pendaftaran Negeri Kedah, surat rasmi kepada penulis, 12 Januari 2015.

4 Khadijah Alavi et.al., "Hamil Luar Nikah Dalam Kalangan Remaja”, Jurnal E-Bangi, UKM, Fakulti Sains Kemasyarakatan \& Kemanusiaan, Vol. 7, No. 1, 2012, hlm. 131-140.

5 Earl Babbie, The Practice of Social Research, $9^{\text {th }}$ Edition, Thomson Learning Inc., USA, 2001, hlm. 36.

6 David Siverman, Interpreting Qualitative Data, $4^{\text {th }}$ Edition, SAGE Publications Ltd., London, 2011, hlm. 16.
} 
Kajian kepustakaan ialah asas utama kajian ini dengan merujuk kajian-kajian terdahulu menerusi pelbagai buku, jurnal dan dokumen yang membincangkan isu remaja hamil luar nikah.

Kaedah tinjauan digunakan untuk mengenal pasti pandangan dua orang responden remaja yang hamil luar nikah tentang penerimaan mereka terhadap kelahiran anak tak sah taraf. Data-data diperoleh dengan menggunakan metode temu bual berstruktur agar isu dan permasalahan yang menjadi fokus kajian dapat dikenal pasti. Pemilihan kaedah ini bersesuaian dengan kajian Iran Herman dan rakan-rakan yang menggunakan kaedah yang sama untuk meninjau persepsi 11 orang Pegawai Kebajikan Masyarakat di seluruh daerah di negeri Kedah terhadap isu penempatan kanak-kanak yang berlaku dalam tiga bentuk iaitu pengangkatan, jagaan pelihara dan jagaan institusi. ${ }^{7}$ Analisis perbandingan dilakukan terhadap data yang dikumpulkan dan dikategorikan kepada lima isu penting sama ada bersifat positif atau negatif dan sama ada terdapat persamaan atau perbezaan dari aspek penjagaan, pendidikan, pengurusan dan kebajikan, emosi dan perasaan serta akhlak dan perubahan sikap remaja tersebut.

\section{DEFINISI ANAK TAK SAH TARAF}

\section{Bahasa Arab}

Anak tak sah taraf disebut walad al-zina bermaksud anak zina atau anak luar nikah. Seseorang anak dihukumkan sebagai anak zina jika kelahirannya melalui persetubuhan tanpa pernikahan yang sah dan dia dinasabkan kepada ibunya sahaja ${ }^{8}$.

\section{Hukum Syarak}

Para fuqaha bersepakat bahawa seseorang anak hanya boleh dinasabkan kepada lelaki dan perempuan yang melakukan

7 Iran Herman et. al., "Isu penempatan Kanak-Kanak: Pandangan Pegawai Kebajikan Masyarakat Di Kedah dan Kebajikan Kanak-Kanak", dlm Azlin Hilma Hillaluddin \& Zarina Mat Saad, Pynt., Penilaian Psikososial Kanak. -Kanak: Isu-Isu Kebajikan dan Perkembangan, Cet. 2, UUM Press, Universiti Utara Malaysia, 2012, hlm. 46.

8 Muhammad Rawwas Qal'aji, al-Mausu'ah al-Fiqhiah al-Muyassarah, Jil. 2, Dar al-Nafa'is, Beirut, 1421H/2000M, hlm. 1983. 
persetubuhan jika perkahwinan mereka sah di sisi hukum syarak atau pemilikan atau syubhah ${ }^{9}$. Sekiranya anak tersebut dilahirkan melalui perzinaan, maka anak itu tidak boleh dinasabkan kepada penzina lelaki dan tidak boleh mewarisi hartanya ${ }^{10}$. Rasulullah SAW bersabda yang bermaksud:

\section{"Anak ialah hak pemilik hamparan (al-firash) sedangkan orang yang berzina (al-'ahir) haknya ialah batu"11}

Menurut al-Nawawi, al-waladu lilfirash bermaksud seseorang lelaki yang mempunyai isteri atau hamba perempuan yang dimiliki akan menjadi firash baginya dan jika lahir anak dalam jangka masa enam bulan dari waktu persetubuhan, maka lelaki tersebut akan menjadi bapa kepada anak tersebut dan kedua-duanya berhak mewarisi harta. Menurut Maliki dan Syafii serta ulama lain mensyaratkan anak dinasabkan kepada lelaki yang menyetubuhi isterinya atau hamba perempuan yang dimiliki dan menjadi firash dari waktu persetubuhan. Abu Hanifah pula tidak mensyaratkan dari waktu persetubuhan melainkan memadai dengan adanya akad. Menurut al-Qurtubi, al- 'ahir dan al-hijr bermaksud "merejam dengan batu kepada penzina yang muhsan"12.

\section{Undang-undang}

Undang-undang keluarga Islam mentafsirkan anak tak sah taraf sebagai "tidak sah taraf, berhubungan dengan seseorang anak, ertinya dilahirkan di luar nikah dan bukan anak daripada persetubuhan syubhah"'13. Dalam konteks anak tak sah taraf, persetubuhan syubhah mempunyai kaitan secara langsung dan ditafsirkan "Persetubuhan

\footnotetext{
9 'Ali Abdul Rahim 'Amir, Ahkam al-Ishtibah Fi al-Nasab Fi Fiqh al-Islami, Cet. 1, Dar al-Salam, Kaherah, 1433H/2012M, hlm. 38.

10 al-Dawish, Ahmad bin Abd al-Razak, Fatawa Al-Lujnah Al-Daimah Lil Mabhus Al- 'Alamiah Wa al-Ifta', Cet. 4, Al-Mamlakah Al-'Arabiyyah As-Su'udiyyah, Muassasah Al-Amirah, Riyadh, 1423H/2002M, hlm. 387.

11 al-Imam al-Hafiz Muslim bin Hujjaj al-Naisaburi, Sahih Muslim, Kitab AlRadha', Bab al-Waladu Lil Firash, Hadis No. 3598, Cet. 2, Dar al-Makrifah, Beirut, 1428H/2007M, hlm. 663.

12 al-Syafii, Muhammad al-Amin bin Abdullah al-Ruumi al-'Alawi al-Harari, Syarah Sahih Muslim, Bab al-Radha', Hadis No. 3493, Juz. 16, Cet. 1, Dar alManhaji, Jeddah, 1430H/2009M, hlm. 102.

13 Enakmen Undang-undang Keluarga Islam Kedah 2008, seksyen 2.
} 
syubhah bermaksud persetubuhan yang dilakukan atas anggapan sah akad nikah akan tetapi sebenarnya akad itu tidak sah (fasid) atau persetubuhan yang berlaku secara tersilap dan termasuk manamana persetubuhan yang tidak dihukum had dalam Islam"14. Begitu juga, "nasab" mempunyai hubungan yang rapat dengan anak tak sah taraf yang ditafsirkan sebagai "keturunan yang berasaskan pertalian darah yang sah" 15 . Ketiga-tiga istilah tersebut saling berkait antara satu sama lain dalam memberi tafsiran yang jelas tentang pensabitan nasab anak tak sah taraf.

\section{Fatwa}

Mesyuarat Jawatankuasa Fatwa Negeri Kedah pada 26 September 2010 mentafsirkan anak tak sah taraf mengikut hukum syarak sebagai:

1. Anak yang dilahirkan di luar nikah sama ada akibat zina, rogol dan dia bukan daripada persetubuhan syubhah atau bukan daripada anak perhambaan.

2. Anak dilahirkan kurang dari enam bulan dua lahzah (saat) qamariah dari waktu imkan ad-dukhul.

3. Anak yang dilahirkan lebih dari enam bulan dua lahzah (saat) qamariah dari waktu imkan ad-dukhul selepas akad yang sah dan ada bukti dari segi syarak bahawa anak tersebut ialah anak luar nikah melalui iqrar (pengakuan) mereka yang berkenaan (suami dan isteri tersebut atau salah seorang daripadanya).

4. Anak tak sah taraf tidak boleh dinasabkan kepada lelaki sama ada lelaki yang menyebabkan kelahirannya atau yang mengaku menjadi bapa kepada anak tersebut. Oleh sebab itu, mereka tidak boleh mewarisi antara satu sama lain, tidak boleh menjadi mahram dan bapa tersebut tidak boleh menjadi wali kepada anak tersebut.

5. Jika lelaki tersebut berkahwin dengan ibu kepada anak tak sah taraf itu dan sabit persetubuhan, maka hubungan anak tersebut dengan lelaki tersebut adalah seperti anak dengan bapa tiri dan mereka adalah mahram ${ }^{16}$.

ibid.

ibid.

16 Jabatan Mufti Negeri Kedah, Fatwa Mengenai Larangan Anak Tak Sah Taraf, Warta Kerajaan Negeri Kedah, Enakmen Mufti dan Fatwa [Kedah Darul Aman] 2008), Jil. 54, No. 13, 23 Jun 2011, hlm. 970. 
Berdasarkan perbincangan di atas, anak tak sah taraf boleh ditakrifkan kepada dua aspek. Pertama, dari sudut fikah, anak tak sah taraf bermaksud anak yang lahir di luar pernikahan yang syarie (anak zina), anak li'an, anak laqit (pungut atau terdampar), anak mangsa rogol dan anak sumbang mahram. Kedua, dari sudut pentadbiran Jabatan Pendaftaran Negara (JPN), anak tak sah taraf ialah anak yang tidak mempunyai dokumen kelahiran akibat perkahwinan ibu bapanya tidak didaftarkan di mahkamah syariah ${ }^{17}$.

\section{NAFKAH DAN HADANAH (PENJAGAAN) ANAK TAK SAH TARAF MENURUT PERSPEKTIF HUKUM SYARAK DAN UNDANG-UNDANG}

\section{Hukum Syarak}

Nafkah ialah kalimah Arab yang berasal daripada infaq bermaksud mengeluarkan. Dari sudut bahasa ialah apa yang dikeluarkan oleh manusia terhadap anak-anaknya. Dari sudut istilah syarak ialah memberi perbelanjaan yang secukupnya daripada makanan, pakaian dan tempat tinggal ${ }^{18}$. Hukum syarak mewajibkan ibu memberi nafkah dan keperluan hidup yang lain kepada anak tak sah taraf. Ini disebabkan anak tak sah taraf hanya dinasabkan kepada ibunya sahaja dan tidak dinasabkan kepada lelaki yang menyetubuhi ibunya ${ }^{19}$. Kewajipan ibu memberi nafkah kepada anak tersebut telah dinyatakan dalam al-Quran yang bermaksud:

\section{"Janganlah menjadikan seseorang ibu menderita kerana anaknya" 20}

Hadanah ialah menjaga dan mendidik kanak-kanak yang masih kecil oleh seseorang yang dipertanggungjawab terhadapnya. Penjagaan tersebut termasuklah mendidik, memimpin, mengawasi dan

\footnotetext{
17 Irwan Mohd Subri, et. al., "Mem”Bin/Ti”Kan Anak Tak Sah Taraf Menurut Perspektif Syarak, Undang-Undang Dan Sosial". Laporan Eksekutif Perundingan Penyelidikan, USIM dengan kerjasama JAKIM, Muzakarah Jawatankuasa Fatwa Kebangsaan, Ipoh, 9 Mac, 2013.

18 Wahbah al-Zuhaili, Al-Figh al-Islami Wa Adillatuhu, Juz. 7, Cet. 3, Dar al-Fikr, Damsyik, 1409H/1989M, hlm. 786.

19 ibid, hlm. 681.

20 al-Quran, al-Baqarah, $2: 233$.
} 
mengatur segala hal ehwal kanak-kanak sehingga umur tertentu ${ }^{21}$. Hukum syarak meletakkan kewajipan kepada ibu untuk menjaga anak tak sah taraf. Perkara ini berdasarkan sabda Rasulullah SAW yang bermaksud:

"Anak ialah hak pemilik hamparan (al-firasy) sedangkan orang yang berzina (al-'ahir) haknya ialah batu',22

\section{Undang-undang}

Seluruh negeri di Malaysia mempunyai enakmen undang-undang keluarga Islam yang tersendiri yang mempunyai peruntukan berkaitan kesahtarafan anak, nafkah dan hadanah anak tak sah taraf. Bagi Wilayah Persekutuan Kuala Lumpur, Labuan dan Putrajaya mengguna pakai Akta Undang-undang Keluarga Islam Wilayah Persekutuan, 1984 (Akta 303). Peruntukan tentang kesahtarafan anak, nafkah dan hadanah anak tak sah taraf adalah hampir sama antara negeri. Oleh sebab itu, penulisan ini hanya mengguna pakai Enakmen Undang-undang Keluarga Islam Kedah, 2008 (EUKIK) sahaja kerana penulisan ini menyentuh isu anak tak sah taraf di daerah Kubang Pasu, Kedah.

Dalam konteks anak tak sah taraf dalam kalangan orang Islam, EUKIK memperuntukkan kewajipan ibu menyara nafkah anak tak sah taraf iaitu:

"Jika seseorang perempuan cuai atau enggan menanggung nafkah seseorang anaknya yang tak sah taraf yang tidak berupaya menanggung nafkah dirinya, melainkan seorang anak yang dilahirkan akibat rogol, Mahkamah boleh, apabila hal itu dibuktikan dengan sewajarnya, memerintahkan perempuan itu memberi apa-apa elaun bulanan yang difikirkan munasabah oleh Mahkamah"23

\footnotetext{
21 al-Khatib, Muhammad al-Syarbini, Mughni al-Muhtaj, Juz. 3, Syirkah Maktabah Wa Matba'ah Mustafa al-Babi al-Halabi Wa Auladuhu, Kaherah, 1377H/1958M, hlm. 452.

22 al-Imam al-Hafiz Muslim bin Hujjaj al-Naisaburi, Sahih Muslim, loc. cit.

23 Enakmen Undang-undang Keluarga Islam Kedah 2008, seksyen 81 (1).
} 
Akta Kanak-Kanak 2001 pula memperuntukkan kewajipan menyara nafkah anak tak sah taraf sama ada Islam atau bukan Islam iaitu:
"Jika sesuatu perintah dibuat dengan meletakkan seseorang kanak-kanak di suatu tempat perlindungan, Mahkamah Bagi Kanak-Kanak boleh memerintahkan ibu atau bapa atau penjaga atau orang lain yang mempunyai jagaan kanak-kanak itu supaya membuat apa-apa sumbangan bulanan mengikut apa-apa cara yang difikirkan patut oleh Mahkamah, setelah mengambil kira kemampuan ibu atau bapa atau penjaga atau orang lain itu"24.

EUKIK 2008 juga memperuntukkan tanggungjawab ibu dan waris ibu terhadap hadanah anak tak sah taraf orang Islam. Peruntukan tersebut menyatakan:

"Penjagaan kanak-kanak tak sah taraf adalah sematamata pada ibu dan saudara mara ibu" 25

Bagi anak tak sah taraf orang Islam dan bukan Islam, Akta Kanak-Kanak 2001 mewajibkan ibu atau bapa atau penjaga menjaga anak tersebut iaitu:

Jika Mahkamah Bagi Kanak-Kanak berpuas hati bahawa mana-mana kanak-kanak yang dibawa ke hadapannya di bawah seksyen 19 atau 25 ialah seorang kanak-kanak yang memerlukan pemeliharaan dan pelindungan, Mahkamah Bagi Kanak-Kanak itu boleh-

a) memerintahkan supaya ibu atau bapa atau penjaganya menyempurnakan bon untuk menjalankan pemeliharaan dan penjagaan yang sepatutnya selama suatu tempoh yang dinyatakan oleh Mahkamah Bagi Kanak-Kanak itu ; ${ }^{26}$

\footnotetext{
24 Akta Kanak-kanak 2001 (Akta 611), seksyen 108 (1).

25 Enakmen Undang-undang Keluarga Islam Kedah 2008, seksyen 86.

26 Akta Kanak-kanak 2001(Akta 611), seksyen 30 (1) (a).
} 


\section{KEWAJIPAN MENANGGUNG NAFKAH ANAK TAK SAH TARAF}

Di Malaysia, undang-undang keluarga Islam di negeri-negeri dan Wilayah Persekutuan mempunyai peruntukan yang mewajibkan ibu menyara nafkah anak tak sah taraf. ${ }^{27}$ Terdapat tiga pihak yang dipertanggungjawabkan memberi nafkah kepada anak tak sah taraf sama ada ibu atau waris ibu atau pemerintah (baitulmal). ${ }^{28}$

\section{Tanggungjawab Ibu}

Pada dasarnya, seseorang bapa bertanggungjawab di hadapan Allah dan masyarakat dalam memberi nafkah dan segala keperluan anakanak. ${ }^{29}$ Kewajipan tersebut berasaskan tiga faktor iaitu perkahwinan, keturunan dan pemilikan. ${ }^{30}$ Firman Allah SWT yang bermaksud:

"Dan kewajipan bapa pula ialah memberi makan dan pakaian kepada ibu itu menurut cara yang sepatutnya. Tidaklah diberatkan seseorang melainkan menurut kemampuannya",31

Begitu juga dalam hadis Rasulullah SAW yang bermaksud:

"Diriwayatkan daripada Sayidatina Aisyah ra bahawa Hindun binti 'Utbah telah berjumpa dengan Rasulullah SAW dan berkata: "Ya Rasulullah, sesungguhnya Abu Suffian (suaminya) seorang yang kedekut. Dia tidak memberi belanja yang cukup untuk saya dan anakanak kami, kecuali jika saya ambil dengan tidak diketahuinya. "Rasulullah SAW menjawab pertanyaan

27 Nora Abdul Hak, "Hak Kanak-Kanak Dari Aspek Hadanah Dan Nafkah: Di Bawah Undang-Undang Keluarga Islam Di Malaysia”. Kertas Kerja Simposium Kebangsaan Kebajikan Kanak-Kanak, Gurney Resort Hotel and Residences, Pulau Pinang, 21 - 22 Julai, 2004, hlm. 4.

28 Wahbah al-Zuhaili, op. cit., hlm. 785.

29 Khadijah al-Nabarawi, Mausu'ah Huquq al-Insan Fi al-Islam, Cet. 1, Dar alSalam, Kaherah, 1427H/2006M, hlm. 41.

30 al-Syarbini, Shamsu ad-din Muhammad bin al-Khatib, Mughni al-Muhtaj, Juz. 3, Dar al-Ma'rifah, Beirut, 1418H/1997M, hlm. 558.

31 al-Quran, al-Baqarah, 2 : 233. 
tersebut dengan bersabda, "Ambillah sekadar yang cukup untuk keperluan kamu dan anak-anak kamu dengan cara yang baik"32

Kedua-dua nas tersebut menegaskan bahawa seseorang bapa bertanggungjawab sepenuhnya menyara nafkah anak-anaknya dan kewajiban tersebut tidak dikongsi bersama dengan pihak lain. ${ }^{33}$ Sekiranya bapa sudah meninggal dunia atau bapa tidak berkemampuan untuk menyara nafkah, maka tanggungjawab menyara nafkah anak berpindah kepada ibu. ${ }^{34}$ Firman Allah SWT yang bermaksud:

\section{"Janganlah menjadikan seseorang ibu menderita kerana anaknya"35}

Al-Qurtubi memetik pendapat jumhur ahli tafsir yang sepakat menyatakan bahawa ibu tidak boleh enggan menyusui anaknya hanya kerana mahu menyusahkan bapanya. Ibu dilarang menuntut upah menyusu melebihi kadar yang munasabah dan bapa tidak boleh menghalang ibu menyusui anaknya apabila ibu menghendakinya. ${ }^{36}$ Kewajipan ibu menyara nafkah anak tak sah taraf disebabkan pertalian darah (nasab) bersamaan dengan kewajipan bapa memberikan nafkah kepada anak yang dinasabkan kepadanya. Antara syarat menyara nafkah anak adalah seperti berikut:

1. Anak itu miskin tidak mempunyai harta sendiri untuk menafkahkan dirinya.

2. Anak itu belum boleh berdikari atas harta yang dimilikinya atau usahanya sendiri.

3. Tanggungjawab nafkah berpindah kepada waris, jika bapa tidak berkemampuan. ${ }^{37}$

32 Jam'u Jawami' al-Ahadis wa al-Asanid wa Maknin al-Sihhah wa al-Sunan wa al-Masanid, Sahih Bukhari, Juz. 3, Kitab al-Nafaqaat, Jam'iah al-Maktabah alIslami, Kaherah, 1431H/2010M, hlm. 1123.

33 al-Marghinani, Burhanuddin Ali ibn Abi Bakr, al-Hidayah Sharh Bidayat alMubtadi, Jil. 3, Daral-Salam, Kaherah, 1420H/2000M, hlm. 653.

34 Wahbah al-Zuhaili, op. cit., hlm. 826-827.

35 al-Quran, al-Baqarah, $2: 233$

36 al-Qurtubi, Abi Abdullah Muhammad bin Ahmad al-Ansori, al-Jami'Li Ahkam Ahkam al-Quran, Juz. 3, Dar al-Hadis, Kaherah, 1428H/2007M, hlm. 143.

37 Muwaffiq al-Din Wa Shams al-Din Ibnu Qudamah, Al-Mughni Wa Syarhu alKabir, Juz. 7, Dar al-Fikr, Beirut, t.th, hlm. 258-259. 
Sekiranya ibu atau bapa tidak mempunyai harta tetapi mempunyai pekerjaan yang cukup untuk dirinya sahaja, maka timbul perselisihan dalam kalangan ulama sama ada wajib atau tidak memberi nafkah kepada anak. Menurut pendapat yang sahih dan disokong oleh majoriti ramai (al-aksarun) wajib memberikan nafkah kepada anak, manakala pendapat yang kedua mengatakan tidak wajib. ${ }^{38}$ Sekiranya anak mempunyai harta atau pekerjaan, maka ibu atau bapanya tidak wajib memberikan nafkah kerana anak tidak lagi berhajat kepada pemberian nafkah sama ada anak tersebut sakit, gila atau buta. Sebaliknya, ibu atau bapa wajib memberikan nafkah jika anaknya fakir, sakit, gila atau masih di bawah umur yang belum mampu bekerja. Menurut Abu Thur, ibu atau bapa berkewajipan memberikan nafkah kepada anaknya walaupun anaknya mempunyai kelebihan rezeki. ${ }^{39}$ Sekiranya anak itu sihat tetapi tidak boleh bekerja, maka timbul persoalan sama ada ibu atau bapa wajib memberikan nafkah kepada anak dalam keadaan tersebut? Al-Rafi' menyatakan wajib sebagaimana anak juga wajib memberikan nafkah jika ibu bapanya berada dalam keadaan yang sama. Menurut pendapat yang sahih menyatakan tidak wajib kerana nas hanya mewajibkan nafkah diberikan kepada anak yang belum cukup umur berbeza dengan anak yang sakit dan gila. ${ }^{40}$

Di negara kita, kebanyakan kes yang dirujuk ke mahkamah syariah hanyalah berkaitan tuntutan selepas perceraian seperti nafkah edah, nafkah anak, tunggakan nafkah isteri dan anak, mutaah, hadanah, harta sepencarian dan sebagainya berbanding dengan kes yang berkaitan kesahtarafan anak. ${ }^{41}$ Kes kesahtarafan anak yang diputuskan oleh mahkamah berkaitan permohonan untuk mendapatkan kebenaran pernikahan menggunakan wali hakim. Secara keseluruhannya, permohonan tersebut diluluskan oleh mahkamah setelah berpuas hati bahawa anak tersebut sebenarnya anak tak sah taraf disebabkan oleh beberapa faktor. Antaranya, termasuklah pasangan ibu bapanya

38 al-Husaini, Imam Taqiyuddin Abi Bakr bin Muhammad, Kifayah al-Akhyar Fi Hilli Gha'yah al-Ikhtisar, Juz. 2, Dar al-Minhaji, Beirut, 1429H/2008M, hlm. 577.

39 ibid.

ibid, hlm. 578.

${ }_{41}^{40}$ Che Maryam Ahmad, "Penentuan Nasab dan Amalannya di Mahkamah Syariah di Malaysia" dlm Zaini Nasohah et. al. Pynt., Syariah dan Undang-Undang. Suatu Perbandingan, Terbitan Pertama, Utusan Publications \& Distributors Sdn Bhd, Kuala Lumpur, 2004, hlm. 268. 
mengaku telah berzina sebelum bernikah, kedua-dua pasangan tidak mempunyai dokumen pernikahan yang sah dan pernikahan tidak didaftarkan di jabatan agama Islam. ${ }^{42}$

Di Kedah, mahkamah syariah tidak pernah memerintahkan seseorang ibu menyara nafkah anak tak sah taraf meskipun terdapat peruntukan dalam seksyen 81, EUKIK 2008 di atas. Hal ini disebabkan tiada permohonan dibuat oleh ibu atau waris ibu, kecuali kes permohonan kesahtarafan anak untuk mendapatkan kebenaran pernikahan menggunakan wali hakim. Dalam kes Siti Nur Azira binti Hj Abdul Ghani ${ }^{43}$, bapa pemohon, Hj Abdul Ghani telah bersekedudukan dengan ibunya, Norhayati binti Teh Idris tanpa dokumen perkahwinan yang sah. Permohonan tersebut bertujuan untuk menentukan kesahtarafan anak dan kebenaran wali hakim sebagai wali nikah. Pada 13 Ogos 2012, mahkamah telah memutuskan bahawa pemohon, Siti Nur Azira binti Hj Abdul Ghani yang lahir pada 9 September 1987 ialah anak tak sah taraf kepada Hj Abdul Ghani dan wali nikah pemohon berpindah kepada wali hakim.

Terdapat juga kes kesahtarafan anak di mahkamah disebabkan oleh Jabatan Pendaftaran Negeri Kedah menolak nama anak dibinkan atas nama bapa apabila hendak memohon kad pengenalan. Dalam kes Jamuri bin Ishak dan Azira binti Aziz ${ }^{44}$, pemohon berkahwin pada 22 Februari 1983. Pada 21 Jun 1998, pemohon kedua melahirkan anak dan diberi nama Mohd Ikhtisam Adwa bin Jamuri. Tujuan permohonan dibuat disebabkan Jabatan Pendaftaran Negeri Kedah meragui status kelahiran anak tersebut apabila pemohon memohon kad pengenalan. Pengesahan status anak tersebut perlu diputuskan oleh mahkamah. Pada 4 Februari 2013, mahkamah memutuskan Mohd Iktisham Adwa ialah anak tak sah taraf kepada Jamuri bin Ishak dan Azira binti Aziz.

\section{Tanggungjawab Waris ibu}

Ibu merupakan pihak yang paling rapat dengan anak tak sah taraf yang dinasabkan kepadanya, jika kelahiran anak tersebut tidak

ibid.

43 Kes Mal No : 02200-006-0181-2012, Mahkamah Tinggi Syariah Kedah

44 Kes Mal No : 02100-006-0028-2013, Mahkamah Tinggi Syariah Kedah. 
melalui perkahwinan yang sah. ${ }^{45}$ Oleh hal yang demikian, ibu berkewajipan memberi nafkah kepada anak tersebut. Sekiranya ibu tidak mampu, tanggungjawab tersebut berpindah kepada ahli waris. Abu Thur menyatakan ahli waris harus memberikan nafkah kepada anak tersebut. ${ }^{46}$ Pandangan Abu Thur berdasarkan firman Allah SWT yang bermaksud:

\section{"Dan waris juga menanggung kewajipan yang tersebut (jika bapa tiada) ${ }^{\prime 47}$}

Menurut Al-Qurtubi, sebahagian ulama seperti Mujahid dan Atha' menyatakan bahawa ahli waris lelaki sahaja membayar kos penyusuan sebagaimana bapa wajib menyaranya ketika hidup. Qatadah berpendapat waris bermaksud anak lelaki dan anak perempuan. Ahmad dan Ishak berpendapat waris membayar kos penyusuan anak kecilnya sekadar sebagai waris sahaja. Menurut Abu Hanifah, kewajipan memberikan nafkah kepada anak kecil dan kos penyusuannya terletak pada mahramnya. At-Tabari berpegang pada pandangan Abu Hanifah sambil menyatakan jika anak lelaki kepada bapa saudara (sepupu) atau orang lain tidak menjadi mahramnya, maka mereka tidak wajib memberikan nafkah kepadanya. Sufyan berpendapat al-waris merujuk saudara kandung anak tersebut yang masih hidup setelah salah seorang daripada ibu bapanya meninggal dunia. Jika bapa meninggal dunia, maka ibu wajib membiayai keperluan anak jika anak tidak memiliki harta. Begitu juga, 'asabah wajib membiayai penyusuan anak berdasarkan bahagiannya daripada harta pusaka. ${ }^{48}$

Wahbah al-Zuhaili menjelaskan tanggungjawab waris ibu memberi nafkah anak tak sah taraf adalah seperti berikut:

"Ibu ialah waris, jadi wajib ke atasnya membiayai nafkah dengan jelas daripada nas al-Quran. Jika anak kecil itu ada nenek dan saudara lelaki maka ke atas nenek satu per enam dan yang selebihnya ditanggung oleh saudara lelaki. Dengan ini jadilah susunan

\footnotetext{
45 'Ali Abdul Rahim 'Amir, op. cit., hlm. 74.

46 al-Husaini, Imam Taqiyuddin Abi Bakr bin Muhammad, op. cit., hlm. 578.

47 al-Quran, al-Baqarah, 2: 233.

48 al-Qurtubi, op. cit., hlm. 144.
} 
pembiayaan nafkah mengikut susunan pewarisan. Maka sebagaimana nenek di sini mendapat habuan pusaka satu per enam, ia wajib membiayai nafkah juga satu per enam dan sebagaimana habuan pusaka yang selebihnya bagi saudara lelaki maka begitu pula ia wajib membiayai nafkah yang selebihnya setelah nenek membiayai satu per enam. Jika berhimpun ibu bapa di sebelah ibu (nenek dan datuk di sebelah ibu) maka pembiayaan nafkah wajib ke atas emak ibu (nenek) kerana ia ialah ahli waris " 49

Yusuf al-Qaradhawi pula menyebut bahawa Islam mengutamakan nafkah terhadap keluarga terdekat dan orang di bawah tanggungannya sebelum diberikan kepada orang fakir, miskin, orang yang berjuang di jalan Allah dan orang yang dalam perjalanan (Ibnu Sabil) ${ }^{50}$. Pandangannya berdasarkan hadis Rasulullah SAW yang bermaksud:

"Satu dinar kamu belanjakan di jalan Allah (berjihad), satu dinar kamu belanjakan bagi hamba (untuk memerdekakan hamba sahaya), satu dinar kamu belanjakan bagi orang miskin dan satu dinar kamu belanjakan bagi keluargamu, yang paling besar pahalanya ialah yang kamu belanjakan untuk keluargamu" 51

\section{Tanggungjawab Pemerintah}

Merujuk hadis sahih yang disepakati bahawa Rasulullah SAW bersabda yang bermaksud:

"Setiap kamu ialah penjaga dan kaтu sетиa bertanggungjawab terhadap jagaanmu" 52

\footnotetext{
49 Wahbah al-Zuhaili, op. cit, hlm. 827-828.

50 Yusuf al-Qaradhawi, Fiqh: Ekonomi Islam, Cet. 1, Terj. Mohamad Dahlan Haji Arshad, Blue-T Publication Sdn. Bhd, Kuala Lumpur, 2009, hlm. 307.

51 al-Imam al-Hafiz Muslim bin Hujjaj al-Naisaburi, Sahih Muslim, Bab Fadhl al-Nafqah 'ala al-'Iyal Wa al-Mamluk, Hadis No. 2308, hlm. 447.

52 al-Bukhari, Sahih Bukhari, Kitab Al-'itqu, Bab al-'Abdu Ra'in Fi Mali Sayyidihi, Hadis No. 2558, hlm. 656.
} 
Hadis di atas menjelaskan bahawa Rasulullah SAW mengingatkan setiap orang ialah pemimpin dan setiap pemimpin hendaklah menunaikan segala kewajibannya. Tanggungjawab sebagai pemimpin berbeza-beza antara satu sama lain sama ada kecil atau besar bergantung pada wilayah penguasaannya seperti gabenor atau khalifah. Setiap pemimpin akan dipersoalkan atas segala urusan yang dipertanggungjawabkan terhadapnya. Penjaga juga merujuk pemimpin yang bersifat amanah dan melakukan pembaikan (islah) dengan adil. Pembaikan dan keadilan akan dipersoalkan sama ada telah ditegakkan terhadap orang yang dijaganya atau sebaliknya ${ }^{53}$

Dalam sistem pemerintahan Islam, baitulmal bertanggungjawab menyediakan segala keperluan kepada orang yang memerlukan bantuan dan memenuhi keperluan mereka. Baitulmal bermaksud tempat untuk menjaga harta kerajaan dan digunakan sebahagian daripadanya untuk nafkah. Hari ini baitulmal dikenali sebagai institusi kewangan atau bank. Baitulmal terbahagi kepada empat bahagian iaitu zakat, harta rampasan perang (ghanimah), harta rampasan (al-Fai) dan harta yang hilang. ${ }^{54}$ Baitulmal juga disebut sebagai khazanah (perbendaharaan) Islam. ${ }^{55} \mathrm{Al}-\mathrm{Kasani}$ dalam membicarakan tanggungjawab baitulmal mengurus harta dan melaksanakan kewajipannya telah menyatakan bahawa:

"Menjadi tanggungjawab baitulmal menyediakan peruntukan untuk membeli ubat-ubatan kepada golongan fakir, membiayai kos rawatan orang yang sakit, mengurus pengebumian jenazah bagi mereka yang tidak mempunyai harta, memberikan nafkah kepada anak-anak yang dijumpai (terdampar), orang yang tak mampu bekerja (daif), orang yang tidak mempunyai ahli keluarga (kerabat) yang bertanggungjawab memberikan nafkah kepadanya, dan seumpamanya. Seseorang imam (pemerintah) hendaklah mengagihkan atau membahagikan hak-hak tersebut kepada orang yang berhak menerimanya" ${ }^{56}$

53 Faisal bin Abdul Gha'rizal Mubarak, "Bab Haq al-Zauj 'ala al-Mar'ah”, dlm. Tadriz Riyadh al-Solehin, Dar al-'Asimah, Riyadh, 1433H/2012M, hlm. 207.

54 Muhammad Rawwas al-Qal'aji, op. cit., hlm. 370.

55 Muhammad Ibrahim al-Haqawi, Mu'jam Gha'rib al-Fiqh Wa al-'Usul, Jil. 1, Dar al-Hadis, Kaherah, 1430H/2009M, hlm. 120.

56 al-Kasani, 'Ala al-Din Abu Bakr bin Mas'ud al-Kasani al-Hanafi, Bada'i alSana ’i, Juz. 4, Matba'ah al-Jamaliyyah, Kaherah, 1328H, hlm. 69. 
Terdapat suatu kisah yang masyhur tentang Sayidina Umar alKhattab dan harta baitulmal. Pada suatu malam, beliau mendapat tahu bahawa seorang wanita bersama anak-anak kecilnya dalam keadaan lapar dan memerlukan makanan. Beliau dengan sendirinya mengambil makanan daripada baitulmal lalu memberikan makanan kepadanya. Wanita tersebut mengucapkan terima kasih kepada Sayidina Umar sambil berkata,"Sesungguhnya Allah berada di antara kami dengan Umar". Kisah ini menunjukkan bahawa seseorang pemerintah bertanggungjawab menjaga hak rakyatnya. ${ }^{57}$ Menurut Ibnu Khuwaiz Mindad, pemerintah berkewajipan mengurus saraan nafkah anak yatim dalam kalangan orang fakir yang tidak memiliki harta diambil daripada baitulmal. Jika pemerintah tidak melakukannya, kewajipan menyara nafkah anak tersebut kembali kepada ahli keluarga (Muslimin) yang terdekat dan yang jauh. Jika ibunya masih hidup, ibu wajib menyusui dan mengurus nafkah anaknya kerana ibu lebih dekat dengan anaknya. ${ }^{58}$

Menurut Syeikh Fakhrurrazi Yub, Baitulmal Negeri Kedah tidak mempunyai peruntukan khusus terhadap anak tak sah taraf. Namun begitu, baitulmal banyak menerima permohonan daripada ibu tunggal yang kematian suami, ditinggal langsung oleh suami atau disebabkan perceraian. Oleh sebab itu, status ibu tunggal yang melahirkan anak tak sah taraf tidak dapat dikenal pasti, sebaliknya maklumat hanya diperoleh berdasarkan borang permohonan sahaja. Hal ini disebabkan tiada aduan rasmi daripada ibu yang memohon bantuan kewangan untuk menyara nafkah anak tersebut. Walau bagaimanapun, terdapat dua kes yang melibatkan datuk dan nenek kepada anak tak sah taraf memohon bantuan kewangan ke baitulmal. Selepas siasatan dijalankan dan memenuhi kelayakan yang disyaratkan, baitulmal mengeluarkan bantuan antara RM 300.00 - RM 500.00 kepada pasangan tersebut ${ }^{59}$.

Di negara kita terdapat agensi-agensi kerajaan yang bertanggungjawab melaksanakan fungsi-fungsi tertentu berkaitan wanita dan kanakkanak, antaranya:

ibid, hlm. 682.

al-Qurtubi, op. cit., hlm. 144.

9 Syeikh Fakhrurrazi Yub, Ketua Bahagian Baitulmal Negeri Kedah, Temu bual telefon dengan penulis, 10 Oktober 2016. 
1. Kementerian Pembangunan Wanita Keluarga dan Masyarakat (KPWKM) yang berperanan untuk memelihara hak-hak wanita, keluarga dan masyarakat dengan adil dan saksama tanpa unsur diskriminasi serta memantapkan institusi keluarga. ${ }^{60}$

2. Jabatan Kebajikan Masyarakat(JKM) mempunyai peruntukan khusus untuk menyara anak tak sah taraf dengan memelihara mereka sejak kecil di Rumah Kanak-Kanak (RKK). Mereka diberikan pendidikan secara formal atau tidak formal seperti kelas fardu 'ain, kem transformasi jati diri dan minda, seminar bijak belajar dan motivasi pelajar, program latihan kemahiran di institusi dan kelas akademik dengan menduduki peperiksaan Ujian Penilaian Sekolah Rendah (UPSR), Penilaian Menengah Rendah (PMR) dan Sijil Pelajaran Malaysia (SPM) sehingga ke institusi pengajian tinggi. ${ }^{61}$

3. Jabatan Pembangunan Wanita (JPW) menyediakan program untuk ibu tunggal seperti Inkubator Kemahiran ibu Tunggal (I-KIT), Jejari Bestari dan Inkubator Keusahawanan Wanita (I-KeuNITA) dengan kerjasama Amanah Ikhtiar Malaysia (AIM) bertujuan untuk meningkatkan penglibatan wanita, termasuklah wanita hamil luar nikah dalam aktiviti keusahawanan agar mereka boleh berdikari tanpa perlu bergantung kepada kerajaan dalam membesarkan anak tak sah $\operatorname{taraf}^{62}$

4. NGO seperti OrphanCARE mengendalikan baby hatcy di Petaling Jaya, Selangor dan Lembaga Kebajikan Perempuan Islam Negeri Kedah (LKPI) mengendalikan Rumah Perlindungan Nurul Hana (RPNH) di Jalan Stadium, Alor Setar. Yayasan OrphanCARE menerima dana daripada kerajaan sebagai insentif menjalankan program seperti forum,

60 Kementerian Pembangunan Wanita, Keluarga dan Masyarakat, [portal rasmi], http://www.kpwkm.gov.my. Capaian pada 25 April 2014.

${ }_{61}$ Jabatan Kebajikan Masyarakat, Pembangunan Kanak-Kanak, [portal rasmi], http://www.jkm.gov.my/mobile/index.php?pagename=pembangunan_kanakkanak\&lang=2, capaian pada 15 Mac 2015.

62 Unit Perancang Ekonomi, Jabatan Perdana Menteri, RMK 10 (2011-2015), [portal rasmi], http://www.pmo.gov.my/dokumenattached/RMK/RMK10_Mds. pdf. capaian pada $15 \mathrm{Mac} 2015$. 
kempen, ceramah dan sebagainya. ${ }^{63}$ Rumah Perlindungan Nurul Hana (RPNH) berdaftar dengan JKM dan diberikan geran tahunan oleh JKM sebagai galakan kepada RPNH yang berganding bahu dengan kerajaan dalam memenuhi keperluan sosial negara. ${ }^{64}$

\section{KEWAJIPAN MENJAGA ANAK TAK SAH TARAF}

Undang-undang keluarga Islam seluruh negeri dan Wilayah Persekutuan memperuntukkan seseorang ibu wajib menjaga anak tak sah taraf. ${ }^{65}$ Terdapat tiga pihak lain yang turut dipertanggungjawabkan menjaga anak tak sah taraf sama ada saudara mara ibu ${ }^{66}$, keluarga angkat atau institusi kebajikan ${ }^{67}$ jika ibu tidak layak menjaga anak tersebut.

\section{Tanggungjawab ibu}

Hukum syarak mewajibkan setiap wanita yang melahirkan anak tak sah taraf menjaga anak tersebut ${ }^{68}$. Kewajipan tersebut selari dengan pandangan fuqaha dalam kalangan Mazhab Hanafi, Maliki, Syafii dan Hanbali bersepakat mengiktiraf ibu dan nenek di sebelah ibu paling berhak terhadap hadanah berbanding bapa, sekiranya berlaku tuntutan hak penjagaan anak sama ada masih bersuami isteri, bercerai atau berpisah akibat kematian suami ${ }^{69}$. Terdapat suatu kisah yang diriwayatkan daripada Amru bin Syu'aib bahawa seorang wanita telah mengadu kepada Rasulullah SAW yang bermaksud:

"Wahai Rasulullah, anak ini dulu pernah menjadikan perutku sebagai wadahnya, tetekku sebagai sumber

63 Siti Naquiah, Pegawai Komunikasi, Yayasan OrphanCARE, email kepada penulis, 29 Disember 2014.

Dato' Daharah Ismail, Pengerusi Lembaga Kebajikan Perempuan Islam Negeri Kedah (LKPI), temubual secara telefon dengan penulis, 16 Januari 2015.

65 Nora Abdul Hak, loc. cit.

66 Enakmen Undang-undang Keluarga Islam Kedah 2008, seksyen 86.

67 ibid, seksyen 87 (1).

68 "Anak ialah hak pemilik hamparan (al-firash) sedangkan orang yang berzina (al-'ahir) haknya adalah batu”. Petikan hadis dari al-Imam al-Hafiz Muslim bin Hujjaj al-Naisaburi, loc. cit.

69 Wahbah al-Zuhaili, op. cit, hlm.720. 
minumnya dan kamarku sebagai rumahnya. Kini ayahnya telah menceraikanku dan ingin merampasnya dariku. Rasulullah SAW bersabda kepada wanita ini, "Kamu lebih berhak terhadapnya selama kamu belum menikah lagi" "70

Di Malaysia, undang-undang keluarga Islam di seluruh negeri dan Wilayah Persekutuan memperuntukkan ibu atau saudara mara ibu ialah pihak yang paling berhak menjaga anak tak sah taraf ${ }^{71}$. Tiada peruntukan undang-undang yang memberi kuasa pada mahkamah syariah mewajibkan bapa biologi atau keluarganya menjaga anak tersebut kerana bapa biologi tiada hubungan nasab dengan anak tak sah taraf. Sekiranya berlaku pernikahan antara ibu dengan bapa biologi, maka anak tak sah taraf hendaklah di"bin" atau di"binti"kan dengan Abdullah ${ }^{72}$ atau nama asma' al-husna yang lain berpangkalkan dengan Abdul ${ }^{73}$.

Menurut Mohd Riddual Ahmad, Jabatan Pendaftaran Negara (JPN) telah melaksanakan arahan Majlis Fatwa Kebangsaan tersebut, meminta ibu atau waris ibu mencadangkan nama anak tak sah taraf terlebih dahulu sebelum didaftarkan. Misalnya, jika anak tersebut dicadangkan nama Ali dan bapa biologi dengan nama Abdullah, maka nama anak tersebut didaftarkan sebagai "Ali bin Abdullah" dalam sijil kelahiran. Sekiranya nama sebenar bapa biologi ialah Abdullah, maka nama anak tak sah taraf perlu didaftarkan dengan nama Abdul yang lain seperti Abdul Rahman. Nama anak tersebut didaftarkan sebagai "Ali bin Abdul Rahman" dan di bawah sijil kelahiran tersebut dibuat catatan tambahan dengan memasukkan "permohonan seksyen 13". Tujuannya adalah untuk mengelakkan kekeliruan kepada nama anak yang dilahirkan melalui pernikahan yang sah jika bapa anak tersebut kebetulan bernama Abdullah atau

$70 \quad$ Jam'u Jawami’ al-Ahadis Wa al-Asanid, Sunan Abi Daud, Juz. 1, Kitab al-Talaq, No. Hadis: 2279, Jam'iyyah al-Maknaz al-Islami, Kaherah, 1421H/2000M, hlm. 388 .

71 Enakmen Undang-undang Keluarga Islam Kedah 2008, seksyen 86.

72 Muzakarah Jawatankuasa Fatwa Majlis Kebangsaan Bagi Hal Ehwal Ugama Islam Malaysia Kali Pertama, http://www.e-fatwa.gov.my/fatwa-kebangsaan/ penamaan-anak-tak-sah-taraf-anak-luar-nikah. capaian pada 31 Mac, 2016.

73 Jabatan Kemajuan Islam Malaysia, Garis Panduan Anak Tak Sah Taraf: Penamaan, Pergaulan dan Hak-haknya, Cet. 1, JAKIM, Kuala Lumpur, 1998, hlm. 9. 
nama-nama lain yang bermula dengan Abdul dan tiada sebarang catatan tambahan di bawah sijil kelahiran tersebut. Dalam keadaan tertentu, Jabatan Pendaftaran Negara (JPN) akan mengosongkan ruangan nama bapa dalam borang pendaftaran sijil kelahiran atau dicatat "maklumat tidak diperoleh". ${ }^{74}$

Begitu juga anak tak sah taraf bukan Islam, maklumat bapa biologi tidak akan dicatatkan dalam sijil kelahiran mereka. Sebaliknya, nama bapa biologi boleh didaftarkan dalam sijil kelahiran jika wujud permohonan bersama oleh ibu dan bapa biologi. Keduaduanya perlu menandatangani bersama dalam sijil kelahiran seperti yang diperuntukkan dalam Seksyen 13, Akta Pendaftaran Kelahiran Dan Kematian 1957. ${ }^{75}$ Selain itu, status mereka sebagai anak tak sah taraf boleh bertukar menjadi sah taraf jika terdapat perintah mahkamah tinggi. Ibu atau bapa anak tersebut boleh mengemukakan permohonan pendaftaran semula anak tak sah taraf di bawah seksyen 17, Akta Pendaftaran Kelahiran Dan Kematian 1957 dengan mengemukakan borang daftar kelahiran JPN.LM01, sijil kelahiran anak, kad pengenalan anak, sijil perkahwinan ibu bapa dan perintah mahkamah. ${ }^{76}$

\section{Tanggungjawab saudara-mara ibu}

Saudara-mara ibu merupakan pihak kedua yang berhak menjaga anak tak sah taraf menurut urutan waris-waris yang dibenarkan oleh hukum syarak ${ }^{77}$. Hak hadanah berpindah kepada saudara-mara ibu disebabkan ibu enggan atau hilang kelayakan menjaga anak tersebut. ${ }^{78}$ Seseorang penjaga anak tak sah taraf hendaklah memenuhi syarat yang ditetapkan iaitu mestilah beragama Islam, sempurna akal, mampu memberi kasih sayang, berakhlak mulia dan menetap

74 Mohd Riddual Ahmad, Penolong Pengarah, Bahagian Kelahiran dan Kematian, JPN Kedah, Temubual secara telefon dengan penulis, 23 Disember, 2015.

75 Jabatan Pendaftaran Negara, "Kelahiran", Jabatan Pendaftaran Negara, [portal rasmi], http://www.jpn.gov.my/soalan_lazim/kelahiran-2/. capaian pada 23 Disember 2015.

76 Jabatan Pendaftaran Negara, "Perkhidmatan Permohonan Daftar Semula Disahtaraf Seksyen 17”, Jabatan Pendaftaran Negara, [portal rasmi], http:// www.jpn.gov.my/perkhidmatan/permohonan-daftar-semula-orang-yangdisahtaraf-seksyen-17/.Capaian pada 23 Disember 2015.

77 Enakmen Undang-Undang Keluarga Islam Kedah 2008, seksyen 82 (2).

78 ibid, seksyen 84 . 
di tempat yang aman damai serta tidak mengundang bahaya dari aspek rohani dan jasmani terhadap anak tersebut. ${ }^{79}$ Selain itu, seseorang penjaga hendaklah berjiwa pendidik dengan memberi pendidikan yang sempurna sama ada secara formal atau tidak formal sejak kecil lagi. Dalam hal ini, mahkamah boleh memerintahkan seseorang penjaga anak tak sah taraf mengutamakan aspek pendidikan dan pelajaran anak tersebut. ${ }^{80}$ Peruntukan ini menjamin hak anak tak sah taraf diberi pertimbangan yang adil sama seperti anak yang sah taraf untuk mendapat pendidikan dan pelajaran sehingga ke tahap yang lebih tinggi seperti yang diperuntukkan oleh undang-undang. Begitu juga dengan aspek kebajikan anak tak sah taraf, mahkamah perlu memberikan perhatian tentang kemahuan seseorang penjaga dan kemahuan anak tersebut jika mereka boleh membuat keputusan sendiri agar penjagaan terhadap mereka sentiasa dipenuhi dengan kebajikan. ${ }^{81}$

Selain itu, mahkamah turut menekankan pemeliharaan harta anak tak sah taraf yang ditinggalkan oleh ibunya sama ada ibunya masih hidup atau meninggal dunia, perlu diuruskan dengan baik mengikut undang-undang. ${ }^{82}$ Bagi menjamin pengurusan yang sempurna terhadap harta anak tersebut, mahkamah perlu mengambil kira faktor-faktor tertentu antaranya, umur dan jantina anak tersebut, perwatakan dan kebolehan penjaga, kemahuan anak tersebut, kedudukan ibu atau bapanya telah meninggal dunia dan hubungan penjaga dengan anak tersebut ketika mengurus hartanya. Seseorang penjaga juga perlulah mendapat keizinan atau menilai kemahuan anak tersebut terhadap pengurusan hartanya jika anak tersebut mampu membuat keputusan sendiri ${ }^{83}$.

Jika ibunya meninggal dunia dan anak tak sah taraf masih kecil, maka harta pusaka yang diwarisinya boleh didaftarkan melalui pemegang amanah dalam kalangan waris ibunya. Namanya boleh didaftarkan sebagai pemilik setelah genap umur 18 tahun dengan membatalkan pemegang amanah melalui perintah mahkamah. Perkara ini diperuntukkan dalam Akta Harta Pusaka Kecil, 1955 iaitu:

\footnotetext{
79 ibid, seksyen 83 .

80 ibid, seksyen 88 (1)

81 ibid, seksyen 87 (2).

82 ibid, seksyen 91 (1).

83 ibid, seksyen 91 (2).
} 
"Pentadbir Tanah hendaklah melalui perintahnya mengarahkan bahagian mana-mana benefisiari budak dalam mana-mana harta tak alih didaftarkan dalam nama orang yang sesuai sebagai pemegang amanah dan hendaklah memasukkan suatu kaveat untuk melindungi kepentingannya semasa sebelum dewasa" "84

Terdapat juga peruntukan yang memberi hak kepada pelantikan pemegang amanah baharu sekiranya pemegang amanah terdahulu meninggal dunia dalam keadaan anak tak sah taraf belum cukup umur. Dalam Akta Harta Pusaka Kecil, 1955 telah diperuntukkan iaitu:

"Jika Pentadbir Tanah mendapati simati ialah pemegang amanah bagi mana-mana orang bagi mana-mana tanah yang dipegang dalam nama simati walaupun tidak didaftar sedemikian, dia hendaklah melainkan dalam apa-apa hal dia fikirkan sesuai merujuk kepada mahkamah memerintahkan harta amanah dipindahkan kepada pemegang amanah yang baru atau kepada benefisiari sebagaimana yang dia fikirkan patut tanpa menjejaskan apa-apa hak atau kepentingan yang didaftarkan dalam tanah manamana pemiutang simati atau mana-mana orang yang mendapat hak milik melalui simati ${ }^{\prime 85}$

\section{Keluarga angkat}

Seseorang ibu atau saudara-mara ibu yang enggan atau hilang kelayakan menjaga anak tak sah taraf, boleh menyerahkannya kepada keluarga angkat. Islam sangat menggalakkan pemeliharaan anak angkat terutamanya anak tak sah taraf demi menjamin akidah Islam anak tersebut dan mengeratkan silaturahim antara mereka. Namun begitu, Islam melarang nama anak tersebut di "bin" atau di "binti" kan dengan nama bapa angkat sebaliknya dikekalkan dengan nama asal

\footnotetext{
${ }^{84}$ Akta Harta Pusaka Kecil (Pembahagian) 1955 (Akta 98), seksyen 13 (2).

85 ibid, seksyen 13 (3).
} 
bapa mereka. ${ }^{86}$ Dalam satu hadis yang diriwayatkan oleh Sa'ad ibn Abi Waqas menyatakan bahawa Rasulullah SAW bersabda yang bermaksud:

"Sesiapa yang mendakwa menjadi anak kepada seseorang selain daripada bapanya sendiri dan dia tahu bahawa orang itu bukanlah bapanya, maka syurga adalah haram untuknya" ${ }^{87}$

Dalam konteks masyarakat di negara kita, pengambilan anak angkat ialah suatu lumrah hidup bagi pasangan yang tidak dikurniai anak setelah lama berkahwin. Dalam hal ini, Islam mengiktiraf penjagaan anak angkat sama seperti anak kandung yang perlu diberi perhatian terutamanya aspek kasih sayang. Pemupukan kasih sayang antara kedua-duanya sangat diperlukan kerana menjadi asas penting untuk membentuk keluarga bahagia ${ }^{88} \mathrm{Hal}$ ini terkandung dalam hadis Rasulullah SAW yang bermaksud:

"Sesiapa yang tidak memiliki sifat kasih sayang, Allah mengharamkan kebaikan ke atasnya" "89

Setiap keluarga angkat bertanggungjawab membesarkan, menjaga kehormatan diri dan membentuk kesejahteraan hidup mereka di

86 al-Quran: al-Ahzab, 33:5 - "Panggilah anak-anak angkat itu dengan ber"bin"kan kepada bapa-bapa mereka sendiri; cara itulah yang lebih adil di sisi Allah. Dalam pada itu, jika kamu tidak mengetahui bapa-bapa mereka, maka panggilah mereka sebagai saudara-saudara kamu yang seagama dan sebagai "maula-maula" kamu. Dan kamu pula tidak dikira berdosa dalam perkara yang kamu tersilap melakukannya tetapi (yang dikira berdosa itu ialah perbuatan) yang disengajakan oleh hati kamu melakukannya. Dan (ingatlah Allah Maha Pengampun lagi Maha Mengasihani”

87 al-Imam al-Hafiz Ahmad bin 'Ali bin Hajr Al-'Asqalani, Fathu al-Bari Bi Syarhi Sahih al-Bukhari, Juz. 13, Kitab al-Faraid, Bab Man Ad'a Ila Ghairi Abihi, Hadis No. 6385, Dar al-Riyyan Li al-Turath, Beirut, 1407H/1986M, hlm. 55.

88 "Kasih sayang ibu", 1 April 2016, http://www.sinarharian.com.my/mobile/ rehal/kasih-sayang-ibu-1.504628. capaian pada 4 Julai 2016.

89 al-Kutub al-Sittah, Sahih Muslim, Bab Fadhl al-Rifqi, Hadis No. 2098, Dar alIslami Li al-Nashri Wa al-Tauzi'e, Beirut, t.th., hlm.1131. 
dunia dan di akhirat seperti yang dikehendaki syariat Islam ${ }^{90}$. Oleh hal yang demikian, anak angkat tidak wajar diperlakukan sebarang perkara yang boleh memudaratkan tubuh badan, akal fikiran dan maruah mereka. Namun begitu, masih terdapat segelintir keluarga angkat yang melakukan penderaan fizikal, mental dan seksual terhadap anak angkat lebih-lebih lagi anak tak sah taraf.

Dari aspek undang-undang, tidak terdapat tafsiran anak angkat dalam Enakmen Pentadbiran Undang-Undang Islam Kedah Darul Aman, 2008, Enakmen Mahkamah Syariah Kedah Darul Aman, 2008 dan Enakmen keluarga Islam Kedah Darul Aman, 2008. Namun begitu, terdapat dua akta yang berkait rapat dengan anak angkat iaitu Akta Pengangkatan 1952 (Akta 257) dan Akta Pendaftaran Pengangkatan 1952 (Akta 253). Akta Pengangkatan 1952 hanya terpakai kepada orang bukan Islam manakala Akta Pendaftaran Pengangkatan 1952 terbuka untuk orang Islam dan bukan Islam. Menurut undangundang, "anak angkat" bermaksud seseorang anak yang telah dibenarkan oleh mahkamah untuk diangkat atau diangkat semula manakala "pengangkat" ertinya seseorang yang dibenarkan oleh suatu perintah pengangkatan untuk mengangkat seorang anak. ${ }^{91}$

\section{Institusi kebajikan}

Institusi kebajikan merupakan alternatif terakhir jika tiada lagi pihakpihak sama ada ibu, waris ibu atau keluarga angkat yang berminat menjaga anak tak sah taraf. Sekiranya anak tersebut boleh membuat keputusan sendiri untuk tinggal di mana-mana institusi kebajikan dan enggan tinggal dengan saudara mara atau keluarga angkat, maka mahkamah syariah boleh memerintahkan pihak berwajib memberikan penjagaan terhadap anak tak sah taraf berdasarkan peruntukan iaitu:

"Walau apa pun peruntukan seksyen 83, Mahkamah boleh pada bila-bila masa dengan perintah memilih untuk meletakkan seseorang kanak-kanak dalam jagaan salah seorang daripada orang-orang yang

\footnotetext{
90 Leha @ Zaleha Muhamat”, "Maruah anak angkat”, http://ww1. utusan.com.my/utusan/info.asp $\mathrm{y}=2000 \& \mathrm{dt}=0327 \& \mathrm{pub}=$ utusan malaysia\&sec=Rencana\&pg=ot_01.htm, capaian pada 4 Julai 2016.

91 Akta Pengangkatan 1952 (Akta 257), seksyen 2.
} 
tersebut dalam seksyen itu atau, jika ada hal yang luar biasa yang menyebabkan tidak diingini bagi kanakkanak itu diamanahkan kepada salah seorang daripada orang-orang itu, Mahkamah boleh dengan perintah meletakkan kanak-kanak itu dalam jagaan mana-mana orang lain atau mana-mana persatuan yang tujuannya adalah termasuk kebajikan kanak-kanak,"92

Selain mahkamah syariah, mahkamah bagi kanak-kanak juga berkuasa memerintahkan mana-mana institusi kebajikan menjaga anak tak sah taraf sama ada Islam atau bukan Islam seperti yang diperuntukkan:
"membuat suatu perintah meletakkan kanak-kanak itu di suatu tempat selamat selama tempoh tiga tahun dari tarikh perintah itu atau sehingga dia mencapai umur lapan belas tahun, mengikut mana-mana yang lebih pendek" ${ }^{93}$

Bagi wanita mengandung anak tak sah taraf yang berdaftar dengan JKM akan ditempatkan sama ada di Pusat Jagaan Sinar Kasih di Batu Gajah, Perak atau Pusat Jagaan Sinar Kasih di Kompleks Penyayang di Sungai Buloh, Selangor. Selepas bersalin, jika mereka enggan menjaga anak tersebut, JKM akan memilih keluarga angkat untuk memeliharanya dalam tempoh usia bayi hingga 2 tahun. Selepas tamat tempoh tersebut, barulah dibuat proses pengangkatan oleh keluarga angkat di JPN. Sebaliknya, jika tiada keluarga angkat, maka anak tak sah taraf akan ditempatkan di institusi kebajikan sehingga mencapai usia 18 tahun. ${ }^{94}$ Antara institusi kebajikan yang menempatkan anak tak sah taraf ialah Rumah Kanak-Kanak (RKK) di bawah Jabatan Kebajikan Masyarakat (JKM) dan Yayasan OrphanCare, sebuah pertubuhan bukan kerajaan (NGO) yang berdaftar dengan JKM yang menyediakan perkhidmatan baby hatch sejak anak tersebut masih bayi lagi. Institusi kebajikan yang wujud di negara kita mempunyai kemudahan tempat tinggal yang selesa dan menyediakan perkhidmatan seperti pendidikan, kesihatan, rekreasi

92 Enakmen Undang-undang Keluarga Islam Kedah, 2008, seksyen 87 (1).

93 Akta Kanak-Kanak 2001 (Akta 611), seksyen 30 (d).

94 Haslinda Abd Samad, Penolong Pengarah, Unit Kanak-Kanak, Jabatan Kebajikan Masyarakat (JKM) Negeri Kedah. Temubual dengan penulis, 13 Januari 2014. 
dan suasana psikologikal bagi perkembangan rohani, jasmani dan emosi. ${ }^{95}$

\section{CONTOH KES}

Terdapat dua orang responden yang telah ditemu bual. Temu bual dengan responden pertama diadakan di rumah ibu saudaranya di Kg. Limbong, Langgar, Alor Setar, Kedah. Responden kedua pula di Rumah Perlindungan Nurul Hana (RPNH), Jalan Stadium, Alor Setar, Kedah.

Responden pertama berumur 24 tahun. Selepas tamat SPM, responden pertama membantu ibu bapanya di warung kopi. Warung tersebut sering kali menjadi tempat tumpuan anak-anak nelayan selepas pulang dari laut. Persekitaran hidupnya di perkampungan nelayan telah mempengaruhinya dalam pergaulan bebas dengan anak-anak nelayan yang tidak lagi bersekolah. Keadaan tersebut semakin memuncak apabila seorang remaja di kampungnya telah menyimpan hasrat untuk mengahwini responden pertama tetapi dihalang keras oleh ibu bapanya. Akhirnya, remaja tersebut berjaya memujuk responden pertama melakukan hubungan seks di rumahnya sewaktu ketiadaan ibu bapanya. Kini, remaja tersebut telah dijatuhi hukuman buang daerah di Perak akibat kesalahan ketum dan dadah. Sewaktu mengandung 5 bulan, responden pertama dihantar ke RPNH dan tinggal di sana sehingga melahirkan seorang anak perempuan. Sewaktu ditemu bual, anak tersebut berusia 9 bulan. Responden pertama terpaksa berpisah dengan keluarga dan tinggal dengan ibu saudaranya apabila ayahnya tidak boleh menerima hakikat bahawa responden pertama telah melahirkan anak tak sah taraf.

Responden kedua pula berumur 26 tahun. Responden kedua mula mengenali teman lelakinya ketika bekerja di salah sebuah restoran di pekan Jitra. Mereka berkenalan selama dua tahun. Teman lelakinya menaruh minat untuk berkahwin dengan responden kedua tetapi

95 Salma Ishak et. al., "Jagaan di Institusi: Apa Pengalaman dan Pandangan Kanak-Kanak”, dlm Azlin Hilma Hillaluddin \& Zarina Mat Saad, Pynt., Penilaian Psikososial Kanak. -Kanak: Isu-Isu Kebajikan dan Perkembangan, Cet. 2, UUM Press, Universiti Utara Malaysia, 2012, hlm. 21. 
tidak pernah datang ke rumah untuk berbincang dengan ibu bapanya. Ketika ditanya tentang peristiwa yang menimpa dirinya, responden kedua sedar apa yang berlaku ke atasnya tetapi tidak berupaya untuk menghalang, tidak menjerit dan tidak menangis tentang apa yang dilakukan oleh teman lelakinya. Responden kedua tidak pula diberi ubat atau minuman yang boleh mengkhayalkannya. Responden kedua tidak memaklumkan kepada ibu bapanya sehinggalah ke suatu malam pada bulan Mei 2014, responden kedua telah mengalami sesak nafas lalu dibawa ke Hospital Jitra. Doktor mengesahkan bahawa dirinya mengandung 5 bulan. Selepas itu, responden kedua dibawa oleh ibu bapanya tinggal di RPNH dan selamat melahirkan seorang anak perempuan.

\section{Penjagaan}

Responden pertama menyatakan:

"Saya nak bela sendiri, tak mau bagi pada orang lain. Masa dok mengandung di Nurul Hana, ada orang yang tak dak anak nak ambik anak saya sebagai anak angkat. Saya tak bagi. Apa jadipun saya nak jaga dia. Saya sayang dan nak bela sampai besar"

Responden kedua pula menyatakan:

"Saya memang ada perasaan nak bela anak tu. Tapi bila mak abah pujuk saya suruh serah kepada keluarga angkat sebab nak jaga maruah dan air muka abah, saya terpaksa setuju. Bila orang tau nanti timbul fitnah kepada saya dan keluarga saya. Nurul Hana berjaya cari keluarga angkat"

\section{Pendidikan}

Responden pertama menyebut:

"Tak bercadang nak sambung mengaji. Kelulusan tak elok. Saya cadang nak masuk kursus menjahit bila anak dah besar nanti" 
Responden kedua pula menyebut:

"Mak abah sangat ambik berat tentang suruhan agama seperti sembahyang berjamaah, mengaji alQuran. Mak dan abah selalu bawa pi dengar kuliah agama di Masjid. Bila dok di Nurul Hana, saya diajar tentang bacaan al-Quran dan Tajwid, Fardu Ain dan sembahyang berjamaah"

\section{Pengurusan dan Kebajikan}

Responden pertama menyatakan:

"Saya yang urus sendiri anak tu. Bagi susu, pakai pampers dan pakai baju. Kadang-kadang mak saudara tolong bantu juga. Saya tolong jual nasi lemak dengan mak saudara di depan SRI ABIM, Jalan Datuk Kumbar mulai 5.00 petang hingga 10.00 malam kecuali Jumaat, cuti. Dia bagi upah kat saya, ikut hasil jualan. Kadangkadang ada juga mak saudara, pak saudara bagi duit untuk beli susu anak",

Responden kedua turut menyatakan:

"Bila tahu kata mengandung, mak dan abah hantar saya ke Nurul Hana. Dok sana hingga bersalin. Bila sakit nak bersalin, mak dan abah mai ambik dan bawa saya pi ke INS Specialist Centre, Alor Setar. Mak abah yang tanggung semua keperluan makan minum. Saya tak ada masalah duit sebab saya kerja sebagai Pembantu TASKA. Gaji sebulan RM 600.00. Saya tak pernah dapat bantuan daripada JKM, Pejabat Zakat atau Baitulmal sebab tak pernah pi berurusan dan tak tahu apa fungsinya"

\section{Emosi dan Perasaan}

Responden pertama menyatakan:

"Saya menyesal apa yang berlaku. Ayah tak bagi balik rumah sebab terlalu marah. Dia tak boleh terima anak 
tu. Mak saudara pi ambik saya di hotel bajet di Shahab Perdana selepas bersalin sehari dan bela saya dengan anak. Saya sanggup tumpang rumah mak saudara sebab nak jaga maruah mak ayah, takut orang tau"

Responden kedua juga menyatakan:

"Saya menghadapi tekanan perasaan bila tau kata mengandung. Pernah terlintas di hati nak buang kandungan tapi bila dah 5 bulan tak boleh nak buat apa dah. Saya terkilan sebab dua tahun berkawan, teman lelaki saya tak pernah beritahu latar belakang keluarga dan alamatnya. Bila jadi macam ni, abah saya tak boleh repot polis sebab tak ada maklumat. Abah tak boleh bincang dengan keluarganya sebab tak tau"

\section{Akhlak dan Perubahan Sikap}

Responden pertama menyebut:

"La ni, dah insaf dan berjanji tak akan mengulangi lagi perbuatan tu. Saya tunai sembahyang dan berdoa agar Allah menunjukkan jalan yang benar di dunia dan di akhirat. Saya reda dengan nasib yang menimpa. Semua ni ketentuan Allah"

Responden kedua pula menyebut :

"La ni saya dah insaf, bertaubat dan berazam tidak akan mengulangi lagi. Saya sedar perbuatan terkutuk tu dilarang oleh Islam"

\section{PERBINCANGAN DAN CADANGAN}

Berdasarkan kes di atas, kedua-dua responden telah terlibat dengan isu hamil luar nikah ketika usia remaja. Menyentuh isu penjagaan anak tersebut, kedua-dua responden dikenal pasti bersikap negatif tentang hubungan seksual yang diperlakukan ke atas mereka. Begitu 
juga, terdapat persamaan antara kedua-dua responden yang boleh menerima hakikat bahawa peristiwa yang berlaku sebagai ketentuan Allah SWT dan bersifat positif terhadap anak yang dikandung bahkan boleh menerima kelahiran anak tersebut sebagai zuriat mereka. Walau bagaimanapun, dalam soal penjagaan anak tersebut kedua-dua responden berbeza pandangan. Responden pertama sanggup memelihara anak tersebut manakala responden kedua tidak sanggup memeliharanya dan menyerahkan kepada keluarga angkat. Hal ini disebabkan pengaruh ibu bapa responden kedua begitu kuat sehingga keinginannya untuk menjaga anak tersebut terhalang hanya dengan alasan untuk menjaga maruah keluarga dan mengelakkan daripada diketahui oleh keluarga dan jiran.

Menyentuh tentang pendidikan, responden pertama tidak berjaya dalam pelajaran. Namun begitu, responden pertama mempunyai keazaman yang tinggi untuk menjalani kursus menjahit suatu masa nanti setelah anaknya semakin membesar dengan harapan ia dapat membantu mengubah kehidupannya bersama anak tersebut. Responden kedua pula boleh dikatakan mempunyai tahap pendidikan yang baik dan sudah bekerja. Responden kedua mendapat pendidikan asas agama dan bimbingan daripada keluarganya. Ternyata bahawa kedua-dua responden bersifat positif tentang pendidikan yang merupakan asas utama untuk memajukan diri terutamanya setelah menghadapi peristiwa hitam dalam hidup mereka.

Menyentuh isu pengurusan dan kebajikan anak tersebut, terdapat dua situasi yang berbeza antara kedua-dua responden tetapi bersifat positif dalam menerima kehadiran anak tersebut. Responden pertama mengambil tanggungjawab sepenuhnya mengurus keperluan anak tersebut tanpa mengharap bantuan orang lain meskipun wujud pertolongan daripada ibu saudaranya. Responden pertama juga bersifat proaktif mencari sumber kewangan dengan menjual nasi lemak untuk menjaga kebajikan anak tersebut walaupun ada sumbangan daripada saudara mara terdekat. Responden kedua lebih banyak bergantung kepada ibu bapanya sama ada ketika berada di RPNH ataupun ketika hendak bersalin. Responden kedua juga tidak mempunyai masalah kewangan kerana mendapat bantuan daripada bapanya dan mempunyai pendapatan tetap bulanan sebagai Pembantu TASKA. Lagipun tidak timbul soal kebajikan kerana anak tersebut diserahkan kepada keluarga angkat sebaik sahaja dilahirkan. Menyentuh tentang emosi dan perasaan, kedua-dua responden 
mempunyai persamaan tentang kesan buruk yang dilalui akibat perbuatan terkutuk tersebut. Responden pertama tidak dibenarkan balik ke rumah dan ayahnya tidak dapat menerima kelahiran anak tersebut. Responden kedua pula tidak mengetahui latar belakang pasangannya sehingga gagal untuk mengambil tindakan undangundang ke atasnya.

Menyentuh tentang akhlak dan perubahan sikap, kedua-dua responden dilihat jujur menjelaskan kedudukan mereka yang telah pun insaf atas perbuatan terkutuk yang dilakukan dan kembali ke pangkal jalan dengan bertaubat kepada Allah SWT. Kedua-dua responden bersifat positif dan mempunyai persamaan atas perubahan sikap dan pembinaan akhlak mereka.

Di sini dikemukakan beberapa cadangan untuk membantu pihak yang berkepentingan bagi menangani masalah remaja mengandung anak tak sah taraf yang semakin berleluasa antaranya seperti berikut:

1. Peranan ibu bapa-kemerosotan asuhan, didikan dan kawalan ibu bapa serta kesibukan ibu bapa dengan pekerjaan dan kegiatan di luar rumah sehingga tiada masa terluang untuk bersama dengan anak-anak mendorong mereka membawa cara hidup tersendiri. ${ }^{96}$ Ibu bapa sebagai pelindung dan pembimbing kepada golongan remaja. Oleh sebab itu, ibu bapa bertanggungjawab memberi pendidikan agama, memberi nasihat dan tunjuk ajar, memantau pergaulan anakanak dengan rakan sebaya, meluangkan masa bersama anakanak agar mereka tidak terjerumus ke dalam aktiviti tidak bermoral.

2. Peranan remaja - Rakan sebaya merupakan faktor terpenting yang boleh mempengaruhi remaja terlibat dalam aktiviti yang tidak sihat. Bagi generasi remaja kini, rakan sebaya merupakan pedoman dan idola dalam pembinaan sahsiah dan tingkah laku mereka. ${ }^{97}$ Remaja lebih banyak menghabiskan masa dengan rakan sebaya berbanding dengan keluarga. Remaja

96 Lai Poh Guat, "Masalah Sosial Di Negeri Selangor Dan Peranan Jabatan Kebajikan Masyarakat", Jurnal Kebajikan Masyarakat, Vol. 25, No. 1, Jun 2003, hlm. 18.

97 Sabita Marican \& Mahmood Nazar Mohamed, "Pencemaran Budaya Remaja: Siapakah Yang Bertanggungjawab", Jurnal Kebajikan Masyarakat, Vol. 18, No. 1, Jun 1995, hlm. 25 . 
perempuan sering merujuk rakan lelaki untuk meluahkan masalah peribadi yang akhirnya mendorong kepada pergaulan bebas dan hubungan seks. Menyedari hakikat ini, bimbingan akhlak yang mulia dan pemantauan ibu bapa tentang rakan sebaya remaja adalah amat penting untuk mencegah remaja terdedah kepada aktiviti salah laku seksual.

3. Peranan Kerajaan - Ledakan teknologi maklumat melalui media elektronik semakin berkembang pesat sejak kewujudan sistem penyiaran melalui televisyen hingga penggunaan komputer secara meluas telah memberi kesan besar kepada golongan remaja masa kini. ${ }^{98}$ Selain mengganggu pelajaran, penggunaan telefon bimbit yang menyediakan pelbagai akses Internet akan memberi peluang kepada pelajar untuk mengakses laman pornografi di sekolah yang mana akan menggalakkan aktiviti sumbang dan hubungan seks di samping membawa implikasi negatif kepada masyarakat. ${ }^{99}$ Kementerian Komunikasi dan Multimedia Malaysia (KKMM) sewajarnya meningkatkan pemantauan secara optimum terhadap penerbitan rancangan dan program yang bersesuaian dalam televisyen dan menyekat penyaluran maklumat yang tidak beretika sama ada melalui Internet atau aplikasi telefon mudah alih yang rata-rata penggunaannya dalam kalangan remaja. Program berbentuk keagamaan, kuliah motivasi kepada ibu bapa dan remaja dalam menangani masalah krisis remaja harus diperbanyak melalui siaran dalam televisyen. Penggunaan smartphone harus dikawal dengan lebih ketat dengan penguatkuasaan undang-undang siber agar remaja lebih berhati-hati dalam melayari laman sesawang yang tidak berfaedah.

\section{KESIMPULAN}

Berdasarkan kajian kes dan perbincangan di atas, ternyata setiap remaja hamil luar nikah boleh menerima hakikat bahawa diri

98 Mansor Ahmad Seman, "Ledakan Media Elektronik", dlm Mansor Ahmad Seman \& Ahmad Sebi, Pynt., Peranan Media Dalam Masyarakat Moden, Cet. 1, Dewan Bahasa \& Pustaka, Kuala Lumpur, 1996, hlm. 86.

99 'Telefon bimbit di sekolah boleh beri kesan negatif kepada pelajar', 27 Julai 2012, para 2, http://www.sinarharian.com.my/telefon-bimbit-di-sekolah-bolehberi-kesan-negatif-kepada-pelajar-1.70681. Capaian pada 14 April 2015. 
mereka mengandungkan anak tak sah taraf. Kelahiran anak tersebut mengikat hubungan nasab dan kasih sayang yang berterusan antara ibu dengan anak tersebut. Mereka boleh menerima kelahiran anak tersebut dan berhasrat untuk memeliharanya. Namun begitu, hasil kajian mendapati remaja sanggup mempertahankan maruah diri dan keluarga dengan menyerahkan anak tersebut kepada keluarga angkat dengan harapan perbuatan terkutuk tersebut tidak boleh dikesan oleh jiran tetangga dan masyarakat di sekeliling. Sebaliknya, ada juga remaja yang sanggup menjaga anak tersebut walaupun terpaksa dibuang oleh keluarga sendiri selain berhadapan dengan risiko sumber kewangan yang terhad dalam membesarkan anak tersebut.

\section{BIBLIOGRAFI}

Abdullah Basmei. (1998) Tafsir pimpinan al-Rahman kepada pengertian Al-Quran Lumpur: Darul Fikri.

Akta Kanak-kanak 2001 (Akta 611).

Akta Harta Pusaka Kecil (Pembahagian) 1955 (Akta 98).

Akta Pengangkatan 1952 (Akta 257).

al-Dawish, Ahmad bin Abd al-Razak. (1423H/2002M.). Fatawa Al-

Lujnah Al-Daimah Lil Mabhus Al- 'Alamiah Wa al-Ifta', Cet.

4., Riyadh: Al-Mamlakah Al-'Arabiyyah As-Su’udiyyah, Muassasah Al-Amirah

al-Husaini, Imam Taqiyuddin Abi Bakr bin Muhammad. (1429H/2008M). Kifayah al-Akhyar Fi Hilli Gha'yah alIkhtisar. (Juz. 2).Beirut: Dar al-Minhaji,

al-Imam al-Hafiz Ahmad bin 'Ali bin Hajr Al-'Asqalani. (1407H/1986M). Fathu al-Bari Bi Syarhi Sahih al-Bukhari, Juz. 13, Kitab al-Faraid, Bab Man Ad'a Ila Ghairi Abihi, Hadis No. 6385. Beirut: Dar al-Riyyan Li al-Turath.

al-Imam al-Hafiz Muslim bin Hujjaj al-Naisaburi. (1428H/2007M).

Sahih Muslim, Kitab Al-Radha', Bab al-Waladu Lil Firash, Hadis No. 3598, Cet. 2. Beirut: Dar al-Makrifah.

al-Kasani, 'Ala al-Din Abu Bakr bin Mas'ud al-Kasani al-Hanafi. (1328H). Bada'i al-Sana'i. (Juz. 4). Kaherah: Matba'ah alJamaliyyah. 
al-Khatib, Muhammad al-Syarbini, Mughni al-Muhtaj. (1377H/1958M). (Juz. 3) . Kaherah: Syirkah Maktabah Wa Matba'ah Mustafa al-Babi al-Halabi Wa Auladuhu. al-Kutub al-Sittah, Sahih Muslim, Bab Fadhl al-Rifqi, Hadis No. 2098, Beirut: Dar al-Islami Li al-Nashri Wa al-Tauzi'e, t.th. al-Marghinani, Burhanuddin Ali ibn Abi Bakr. (1420H/2000M). alHidayah Sharh Bidayat al-Mubtadi. (Jil. 3). Kaherah: DaralSalam.

al-Qurtubi, Abi Abdullah Muhammad bin Ahmad al-Ansori. (1428H/2007M.)

al-Jami'Li Ahkam Ahkam al-Quran. (Juz. 3) Kaherah: Dar al-Hadis. al-Syafii, Muhammad al-Amin bin Abdullah al-Ruumi al-'Alawi alHarari. (1430/2009). Syarah Sahih Muslim, Bab al-Radha', Hadis No. 3493, (Juz. 16). Cet. 1., Jeddah: Dar al-Manhaji. al-Syarbini, Shamsu ad-din Muhammad bin al-Khatib, Mughni alMuhtaj. (1418H/1997M). (Juz. 3). Beirut: Dar al-Ma'rifah. 'Ali Abdul Rahim 'Amir. (1433/2012M) Ahkam al-Ishtibah Fi alNasab Fi Fiqh al-Islami. Cet. 1. Kaherah: Dar al-Salam. Che Maryam Ahmad. (2004). Penentuan Nasab dan Amalannya di Mahkamah Syariah di Malaysia. Dlm Zaini Nasohah et. al. Pynt., Syariah dan Undang-Undang: Suatu Perbandingan, Terbitan Pertama, Utusan Publications \& Distributors Sdn Bhd, Kuala Lumpur, 2004, hlm. 268.

Dato' Daharah Ismail, Pengerusi Lembaga Kebajikan Perempuan Islam Negeri Kedah (LKPI), temu bual secara telefon dengan penulis, 16 Januari 2015.

David S. (2011). Interpreting qualitative data. ( $4^{\text {th }}$ edn. $)$. London: SAGE Publications.

Earl, B. (2001). The practice of social research. ( $9^{\text {th }}$ edn.). USA: Thomson Learning.

Enakmen Undang-undang Keluarga Islam Kedah 2008.

Faisal bin Abdul Gha'rizal Mubarak. (1433H/2012M). Bab Haq alZauj 'ala al-Mar'ah. Dlm. Tadriz Riyadh al-Solehin, Riyadh: Dar al-'Asimah, hlm. 207.

Fariza Md. Sham. (2013). Ciri-ciri remaja berisiko: Kajian literatur. Islamiyyat, UKM, 35 (1) hlm.111 - 119.

Haslinda Abd Samad, Penolong Pengarah, Unit Kanak-Kanak, Jabatan Kebajikan Masyarakat (JKM) Negeri Kedah, temu bual dengan penulis, 13 Januari 2014. 
Iran Herman. (2012). Isu penempatan kanak-kanak: Pandangan Pegawai Kebajikan Masyarakat di Kedah dan kebajikan kanak-kanak. Dlm. Azlin Hilma Hillaluddin \& Zarina Mat Saad, Pynt., Penilaian Psikososial Kanak-Kanak: Isu-Isu Kebajikan dan Perkembangan, Cet. 2, UUM Press, Universiti Utara Malaysia, 2012, hlm. 46.

Irwan Mohd Subri. (2013). "Mem"Bin/Ti"Kan Anak Tak Sah Taraf Menurut Perspektif Syarak, Undang-Undang Dan Sosial". Laporan Eksekutif Perundingan Penyelidikan, USIM dengan kerjasama JAKIM, Muzakarah Jawatankuasa Fatwa Kebangsaan, Ipoh, 9 Mac, 2013.

Jabatan Kebajikan Masyarakat, Pembangunan Kanak-Kanak, [portal rasmi], Dicapai daripada http://www.jkm.gov.my/mobile/ index.php?pagename $=$ pembangunan_kanak-kanak\&lang $=2$

Jabatan Kemajuan Islam Malaysia, Garis Panduan Anak Tak Sah Taraf: Penamaan, Pergaulan dan Hak-haknya, Cet. 1, JAKIM, Kuala Lumpur, 1998.

Jabatan Mufti Negeri Kedah, Fatwa Mengenai Larangan Anak Tak Sah Taraf, Warta Kerajaan Negeri Kedah, Enakmen Mufti dan Fatwa [Kedah Darul Aman] 2008), Jil. 54, No. 13, 23 Jun 2011.

Jabatan Pendaftaran Negara, "Kelahiran", Jabatan Pendaftaran Negara, [portal rasmi], Dicapai daripada http://www.jpn.gov. my/soalan_lazim/kelahiran-2/

Jabatan Pendaftaran Negara, "Perkhidmatan Permohonan Daftar Semula Disahtaraf Seksyen 17", Jabatan Pendaftaran Negara, [portal rasmi], Dicapai daripada http://www.jpn.gov. my/perkhidmatan/permohonan-daftar-semula-orang-yangdisahtaraf-seksyen-17/

Jabatan Pendaftaran Negeri Kedah, surat rasmi kepada penulis, 12 Januari 2015.

Jam'u Jawami' al-Ahadis wa al-Asanid wa Maknin al-Sihhah wa al-Sunan wa al-Masanid, Sahih Bukhari, Juz. 3, Kitab al-Nafaqaat, Kaherah: Jam'iah al-Maktabah al-Islami, $1431 \mathrm{H} / 2010 \mathrm{M}$.

Jam'u Jawami' al-Ahadis Wa al-Asanid, Sunan Abi Daud, Juz. 1, Kitab al-Talaq, No. Hadis: 2279, Kaherah: Jam'iyyah alMaknaz al-Islami,1421H/2000M.

Kasih sayang ibu. (2016, April 1). Sinar Harian. Dicapai daripada http://www.sinarharian.com.my/mobile/rehal/kasih-sayangibu- 1.504628 
Khadijah Alavi. (2012). Hamil luar nikah dalam kalangan remaja. Jurnal E-Bangi, UKM, Fakulti Sains Kemasyarakatan \& Kemanusiaan, 7(1), hlm. 131-140.

Khadijah al-Nabarawi, Mausu'ah Huquq al-Insan Fi al-Islam. (1427H/2006M.) Cet. 1, Kaherah: Dar al-Salam.

Kementerian Pembangunan Wanita, Keluarga dan Masyarakat, [portal rasmi], Dicapai daripada http://www.kpwkm.gov.my, capaian pada 25 April 2014.

Kes Mahkamah Tinggi Syariah Kedah.

Lai Poh Guat. (2003). Masalah sosial di Negeri Selangor dan peranan Jabatan Kebajikan Masyarakat. Jurnal Kebajikan Masyarakat, (25), 1, Jun, hlm. 18.

Leha@Zaleha Muhamat. Maruah anak angkat. Utusan Malaysia. Dicapai daripada http://ww1.utusan.com. $\mathrm{my} / \mathrm{utusan} /$ info.asp? $\mathrm{y}=2000 \& \mathrm{dt}=0327 \& \mathrm{pub}=\mathrm{utusan}_{-}$ malaysia\&sec=Rencana\&pg=ot_01.htm

Mansor Ahmad Seman. (1996). Ledakan Media Elektronik. Dlm. Mansor Ahmad Seman \& Ahmad Sebi, Pynt., Peranan Media Dalam Masyarakat Moden, Cet. 1, Kuala Lumpur: Dewan Bahasa \& Pustaka,hlm. 86.

Mohd Riddual Ahmad, Penolong Pengarah, Bahagian Kelahiran dan Kematian, JPN Kedah, temu bual secara telefon dengan penulis, 23 Disember, 2015.

Muhammad Ibrahim al-Haqawi. (1430H/2009M.). Mu'jam Gha'rib al-Fiqh Wa al-'Usul, Jil. 1. Kaherah: Dar al-Hadis.

Muhammad Rawwas Qal'aji, al-Mausu'ah al-Fiqhiah alMuyassarah. (1421H/2000M.) Jil. 2.Beirut: Dar al-Nafa'is.

Muwaffiq al-Din Wa Shams al-Din Ibnu Qudamah, Al-Mughni Wa Syarhu al-Kabir, Juz. 7. Beirut: Dar al-Fikr t.th.

Muzakarah Jawatankuasa Fatwa Majlis Kebangsaan Bagi Hal Ehwal Ugama Islam Malaysia Kali Pertama, http://www.efatwa.gov.my/fatwa-kebangsaan/penamaan-anak-tak-sahtaraf-anak-luar-nikah, capaian pada $31 \mathrm{Mac}, 2016$.

Nora Abdul Hak. (2004). Hak Kanak-Kanak dari Aspek Hadanah dan Nafkah: Di Bawah Undang-Undang Keluarga Islam di Malaysia. Kertas Kerja Simposium Kebangsaan Kebajikan Kanak-Kanak, Gurney Resort Hotel and Residences, Pulau Pinang, 21 - 22 Julai, 2004, hlm. 4.

Sabita Marican, \& Mahmood Nazar Mohamed. (1995). Pencemaran budaya remaja: Siapakah yang bertanggungjawab. Jurnal Kebajikan Masyarakat, 18,(1), Jun 1995, hlm. 25. 
Salma Ishak. (2012). Jagaan di Institusi: Apa Pengalaman dan Pandangan Kanak-Kanak. Dlm Azlin Hilma Hillaluddin \& Zarina Mat Saad, Pynt., Penilaian Psikososial Kanak. -Kanak: Isu-Isu Kebajikan dan Perkembangan, Cet. 2, UUM Press, Universiti Utara Malaysia, 2012, hlm. 21.

Siti Naquiah, Pegawai Komunikasi, Yayasan OrphanCARE, email kepada penulis, 29 Disember 2014.

Syeikh Fakhrurrazi Yub, Ketua Bahagian Baitulmal Negeri Kedah, temu bual telefon dengan penulis, 10 Oktober 2016.

Telefon bimbit di sekolah boleh beri kesan negatif kepada pelajar. (2012, Julai 27). Sinar Harian. Dicapai daripada http://www. sinarharian.com.my/telefon-bimbit-di-sekolah-boleh-berikesan-negatif-kepada-pelajar-1.70681

Unit Perancang Ekonomi, Jabatan Perdana Menteri, RMK 10 (20112015), [portal rasmi],

http://www.pmo.gov.my/dokumenattached/RMK/RMK10_Mds. pdf, capaian pada 15 Mac 2015.

Wahbah al-Zuhaili, Al-Figh al-Islami Wa Adillatuhu. (1409H/1989M). Juz. 7, Cet. 3. Damsyik: Dar al-Fikr.

Wan Hamzah Wan Paie. Isu Terhadap Jawapan TMDN mengenai statistik kes rogol gadis bawah umur. Kenyataan Media, 21 Mac 2014. Dicapai daripada http://www.moha.gov.my/index. php/en/kenyataan-media-akhbar/1513-isu-terhadap-jawapanyb-tmdn-mengenai-statistik-kes-rogol-gadis-bawah-umur/21 Mac 2014

Yusuf al-Qaradhawi. (2009). Fiqh: Ekonomi Islam, Cet. 1, Terj. Mohamad Dahlan Haji Arshad, Kuala Lumpur: Blue-T Publication. 